BForesty for Develooment - Proceedings of the Annutat Forestry Sympasium 1995, Sri Lanka, 15. 16 December 1995. (Eds. Amarasekers, H S and Banyard, S G). Published by Department of Forestry and Environmenfal Solence, Umwersily of Sriv Jayewardenepura, Sri Lanka (9996)

\title{
RELATIONSHIP BETWEEN SOIL CONDITIONS AND THE OCCURRENCE OF ROOT ROT DISEASE IN A FOREST NURSERY AT KUMBALPOLA.
}

\author{
G.Kathiravelu¹, K.M.E.P.Tissera ${ }^{2}$ \\ 'Department of Forestry and Environmental Seience \\ 'Department of Botany, University of Sri Jayewardencpura
}

\begin{abstract}
Soil conditions influence the seasonal development and geographical distribution of soil-borne fungi and devclopment of root diseases. Diseased seedlings and soil samples were collected from Kumbalpola nursery which is one of the largest Teak nurseries in Sti Lanka. The results of the survey showed that almost $17 \%$ of soedling were affected by root rot Rhizoctonia species, one of the soil inhabitants, was identified as the causal organism of root rot of Teak. The fungal: populations of infested and non-infested soils of the nursery were studied. The environmental factors which influence the severity of the disease, including soil mosture, soil $\mathrm{pH}$, soil temperature, organic carbon, organic matter and nitrogen contents, were compared in both soils.
\end{abstract}

\section{INTRODUCTION}

Tcak is a valuable timber species in Sri lanka. At the seedling stage. Teak is susceptible to several diseases. Root rot of Teak seodlings was reported in Sri Lanka at Kumbalpola nursery in 1993. Kumbalpola is located in Kurunagella district. The altitude is 0 to $100 \mathrm{~m}$, mean annual temperature is 25 to $27.5^{\circ} \mathrm{C}$ and the annual rainfall is 1500 to $2000 \mathrm{~mm}$. The soil of Kumbalpola nursery consists of red yellow podzolic soil with strongly mottied sub soil and low humic gley soil. The soil is well drained, moderately fine textured and strongly acidic, A Rhizoclonia spocies was identified as the causative organism of root rot disease. It causes serious visual damage to tiny Teak socdlings.

Studies were undertaken to understand the effect of soil environment on the incidence of root rot disease in the Kumbalpola nursery.

\section{MATERIALS AND METHODS}

A field survey was carried out at Kumbalpola nursery in 1993 to estimate the economic loss due to root rot disease at the nursery stage (about $52 \%$ ). Soil samples were collected from different depths, (ranging from 0 to $3^{\prime \prime}, 3$ to $6^{\prime \prime}, 6$ to $9^{\prime \prime}$ ) of non- 
infested and infested soils of the nursery beds. The soil samples were stored in polythene bags with a view to determine moisture content, $\mathrm{pH}_{\text {, }}$ organic carbon, organic matter content, nitrogen content and soil fungal population. Czapek-dox agar medium was used for the study of the fungal population of the soil. Soil temperatures were also measured at the sample spots.

\section{SOIL ANALYSIS}

The following steps were taken:

- Moisture content was obtained by taking the fresh weight of the soil before obtaining the dry sweight after drying in an oven at $105^{\circ} \mathrm{C}$

- The $\mathrm{pH}$ was measured using a $\mathrm{pH}$ meter.

- The percontage of organic carbon and organic matter of the soil was determined by the Walkey Black method.

- The total nitrogen content of the soil at different depths for both soil types was determined by the Kjeldhal method.

- The number of fungal colonies in the soil samples was determined by means of the soil dilution plate method. Morphological characteristics of the mycelium, such as colour of the mycelium, septation, together with shape and kind of spores, reproductive structures and fungal tissues were used for identification.

\section{RESULTS}

The highest temperature was recorded in the top soil of the non-infested region and the lowest temperature was recorded in infested deeper soil (Table 1). The soil moisture content was as high as $35.9 \%$ in infested soil whereas in the non-infestod soil it was $27.15 \%$ (Figure 1). The soil pH was higher in the top soils than in the lower soils for both sites (Figure 2). Both soil organic carbon and organic matter contents were higher in the infested top soil than in the non-infested soils (Figures 3 and 4). The highest value for the soil nitrogen content was observed in the infested top soil $(0.066 \%$ ) (Figure 5 ).

Table 1 Temperature of Soil at different depths

\begin{tabular}{lcc}
\hline Soil Depth & \multicolumn{2}{c}{ Temperature ${ }^{\circ} \mathrm{C}$} \\
\hline 0 to $3^{\prime \prime}(0-7.6 \mathrm{~cm})$ & Infested soil & Healthy soil \\
3 to $6^{\prime \prime}(7.6-15.2 \mathrm{~cm})$ & 33 & 34 \\
6 to 9 " $(15.2-22.9 \mathrm{~cm})$ & 28 & 33 \\
\hline
\end{tabular}

Ambient temperature was $32^{\circ} \mathrm{C}$ 


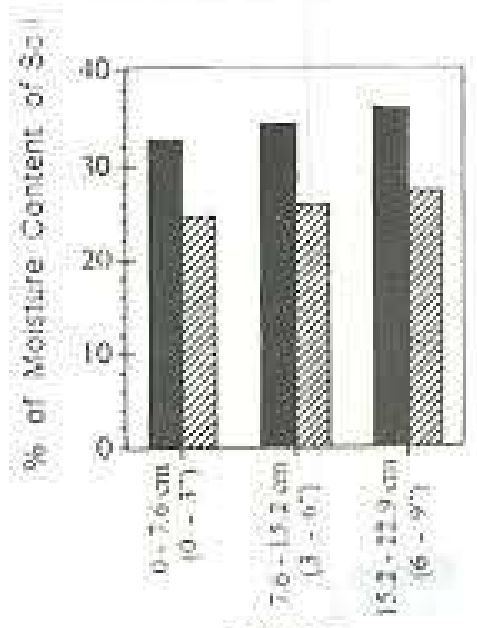

Depths

$$
\begin{aligned}
& \text { 可 Inlected Sol } \\
& \text { ØS Healthy Soi! }
\end{aligned}
$$

Figure 1 - Percentage Moisture Content of soil in nursery beds

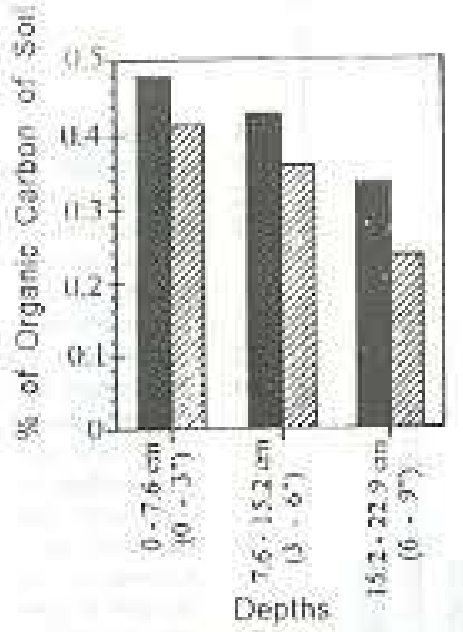

$$
\begin{aligned}
& \text { Intected Soil } \\
& \text { Healthy Soil }
\end{aligned}
$$

Figure 3 - Percentage Soil Organic Carbon in nursery beds

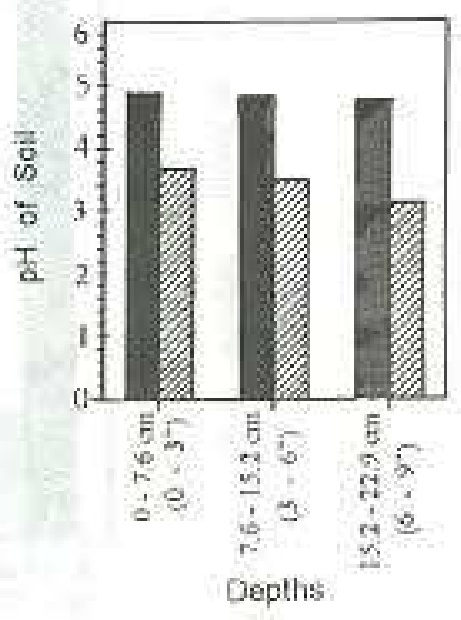

infected Soil

VR Healthy Svil

Figure 2 - Soil $\mathrm{pH}$ in nursery beds

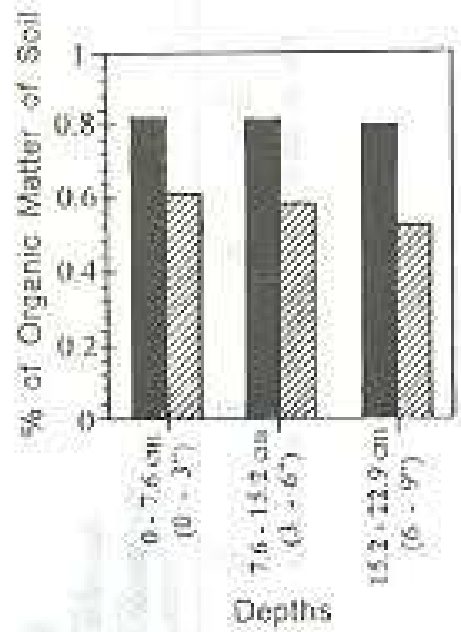

Infected Soil
Healthy Soil
Figure 4 - Percentage Organic

Matter Content of healthy and infested soil in nursery bed 


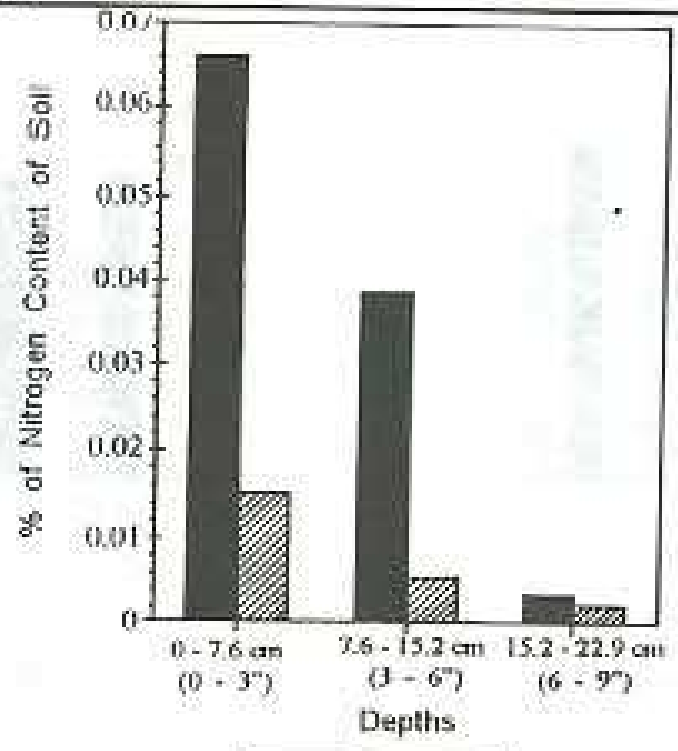

Figure 5 - Percentage nitrogen content of soil at different depths of nursery beds

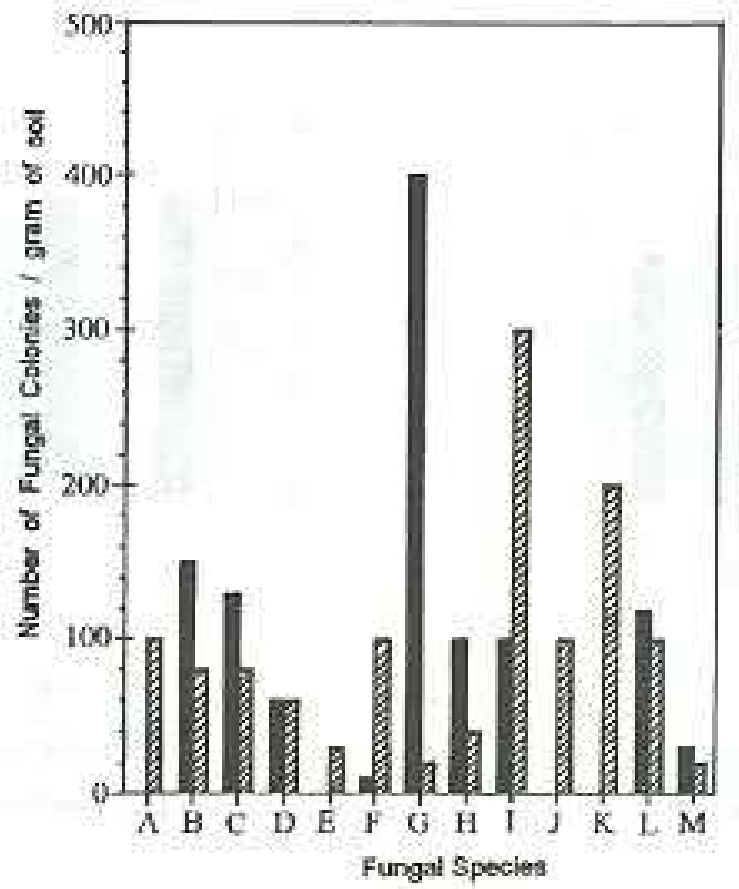

A. Ganatobolirys sp.

B - Verficitum sp

C. Fisfrian sp.

D - Ponicsiliem $\equiv$ p (Yelow in colous)

E - Geotrichum sp.

F. Trichoderma

G. Asporginus niger

H - Penicifium sp. (Bluish green)

1. Ahirogurs sp

f. Aspergillos sp. (Yollowish greon)

X. Cardana sp.

L - Asporainces sp. (Green in colour) M - fonizoctonia sp

Infected Soil $\mathbb{Z Z}$ Healthy Soil

Figure 6 - Soil microbial population in the nursery beds 
The distribution of the soil fungal population in infested and non-infested regions of nursery beds was determined. The numbers of Aspergillns species ( $G \& L$ ), Penicillium species $(\mathrm{H})$. Verticillium species and Fissarium species were higher in infested soil than in non-infested soil. The Rhizopus species count was higher in healthy soil. Gonatoboirys species, Geotrichum species, Aspergillus species (J) and Cordana species were only present in healthy soil. The number of Trichoderma viridae was lower in infested soil than in non-infested soil (Figure 6).

\section{DISCUSSION}

Normally, the termperature of top soil is higher then that of deeper soil since the surface soil is in direct contact with the sunlight. But in an infested region, the soil temperature valuts were lower than in bealthy soils. This result indicates that a relatively low temperature may be suitable for the growth of the pathogen. The $\mathrm{pH}$ of soil is an important factor regarding the ocurrence and severity of plant disease causad by certain soil-borne pathogens. (Fungi are acid tolerant and can grow at a pH as low as 3.5 although their optimum range is $\mathrm{pH} 5$ to 6). Diseases are more sericus in areas where soil $\mathrm{pH}$ favours particular pathogens. Infested soil showed a relatively low pH range which is probably suitable for the growth of the pathogen. The higher carbon content in top soil when compared with decper soil may be due to the addition of considerable amounts of organic matter and organic debris from dead leaves and fertilizer. The higher level of nitrogen content in top soils, also indicates a high degree of decomposition of the litter layer and fertilizer use. The number of Rhizoctonia species was bigher in infested soil than in healthy soil. In the order Agromycetales however, growth characteristics are such that hyphae alone ean compcnsatu for lack of sponilation. These characteristics include adaptability of hyphac to a wide range of soil conditions, rapid growth rate and resistanoe of hyphat fragment or sclerotia to adverse environments bocause of spocial wall and photoplasmic properties. It has been found that Trichderma viridae can be used as a biological control ageat to control some fungal pathogens. The results show that at large number of Aspergillus and Penicilinm species appear in infested soil. This may be attributed to their production of a large number of small thermo-tolerant conidia that can survive better in soil.

\section{CONCLUSION}

Physical factors, chemical factors and biological factors such as temperature, acration, moisture content, $\mathrm{pH}$, organic matter content, organic carbon content, nitrogen content and Trichoderna viridae seems to determine the soil fungal population and the occurrence of disease incidence in Teak nurserics; 